Jurnal Sikola: Jurnal Kajian Pendidikan dan Pembelajaran

VOL. 1 NO. 1 SEPTEMBER 2019

http://sikola.ppj.unp.ac.id

Email: sikola@ppj.unp.ac.id

ISSN: 2686-3413 (Print) 2715-1735 (Online)

DOI: https://doi.org/10.24036/sikola.v1i1.13

\title{
Hubungan Antara Perhatian Orang Tua dengan Hasil Belajar Sosiologi Kelas XI IPS di SMAN 2 Padang
}

\author{
Muz Dalifah', Junaidi Junaidi² \\ 1,2Universitas Negeri Padang \\ Email: sachikomuzda@gmail.com, junaidiunp@fis.unp.ac.id.
}

\begin{abstract}
Abstrak
Penelitian ini dilatarbelakangi oleh ketertarikan peneliti dalam melihat hasil belajar siswa di SMAN 2 Padang yang rendah akibat kurangnya perhatian orang tua terhadap hasil belajar anak. Penelitian ini bertujuan untuk mengetahui hubungan antara perhatian orang tua dengan hasil belajar sosiologi siswa kelas XI IPS SMAN 2 Padang. Penelitian ini dianalisis dengan teori yang dikamukakan oleh Gegne dan Berliner. Penelitian ini menggunakan pendekatan kuantitaif Ex-Post Facto, teknik pemilihan proportional random sampling dengan jumlah responden 50 orang. Pengumpulan data dilakukan dengan cara menyebarkan angket, data sekunder berupa hasil belajar dan dokumentasi yang dianalisis dengan menggunakan teknik analisis data deskriptif data. Hasil penelitian menunjukkan bahwa terdapat korelasi yang signifikan antara variabel perhatian orang tua dengan hasil belajar sosiologi siswa kelas XI IPS di SMA Negeri 2 Padang yang dibuktikan dengan koefisien korelasi $\left(\mathrm{r}_{\mathrm{xy}}\right) 0.778>\mathrm{r}$ tab (0.279).
\end{abstract}

Kata Kunci: Perhatian Orang Tua, Hasil Belajar, Siswa

\section{Abstract}

The idea of this study is motivated by the interest of researchers in looking at student learning outcomes at SMAN 2 Padang which is low due to lack of parental attention to children's learning outcomes. This study aims to determine the relationship between parental attention and the sociology learning outcomes of XI IPS students at SMAN 2 Padang. This research was analyzed by a theory by Gegne and Berliner.This study uses the Ex-Post Facto quantitative approach, proportional random sampling selection technique with a number of respondents 50 people. Data collection is done by distributing questionnaires, secondary data in the form of learning outcomes and documentation which are analyzed using descriptive data analysis techniques. The results showed that there was a significant correlation between the variables of parental attention and the sociology learning outcomes of students of class XI IPS in Padang 2 Public High School as evidenced by the correlation coefficient ( $r x y$ ) 0.778> r tab (0.279).

Keywords: Parental Attention, Learning Outcomes, Students

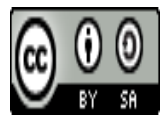

Received: August 30, 2019 Revised: August 8, 2019 Available Online: September 30, 2019

Jurnal Sikola: Jurnal Kajian Pendidikan dan Pembelajaran Vol. 1, No. 1, Th. 2019 


\section{Pendahuluan}

Pendidikan merupakan suatu kebutuhan yang sangat penting dalam kehidupan manusia. Melalui pendidikan manusia dapat mengembangkan dirinya maupun mendayagunakan potensi alam dan lingkungan sosial untuk kepentingan hidupnya. Pendidikan juga merupakan sesuatu kebutuhan pokok dalam pembangunan bangsa dan negara. Menurut Syah (Aris Nanda, Yunus, \& Hayati, 1991) Pendidikan jika diartikan sebagai suatu proses dengan metode-metode tertentu sehingga memperoleh pengetahuan, pemahaman dan cara bertingkah laku yang sesuai kepada kebutuhan.

Menurut (soerjono, 2003) Salah satu mata pelajaran yang menunjang usaha pencapaian tujuan pendidikan nasional adalah Sosiologi. Sosiologi merupakan cabang ilmu yang mengkaji gejala-gejala atau peristiwa-peristiwa sosial yang secara nyata terjadi dalam masyarakat. Sosiologi mempelajari masyarakat dalam keseluruhannya dan hubungan-hubungan antara orang-orang dalam masyarakat yang ada disekitar lingkungan. Menurut Depdiknas (Melgawati, 2014) Materi pelajaran Sosiologi mencakup konsep-konsep dasar, pendekatan, metode dan teknik analisis dalam pengkajian berbagai fenomena dan permasalahan yang ditemui dalam kehidupan nyata di masyarakat.

Yang kemudian disempurnakan menurut No. 118/U/2002 ( I Wayan Dwija, 2008) Surat Keputusan Menteri Pendidikan Nasional Republik Indonesia, tertanggal 22 Juli 2000, dipaparkan bahwa tujuan pelajaran Sosiologi di Sekolah Menengah Atas adalah memperluas cakrawala pengetahuan, mengembangkan sikap dan perilaku siswa yang rasional.

Pembelajaran sosiologi di berikan kepada siswa kelas X, XI, XII Jurusan IPS sebagai mata pelajaran wajib dan sedangkan siswa jurusan lain tidak ada peminatan pelajaran sosiologi di SMAN 2 Padang dan sosiologi diajarkan di kelas X, XI, XII IPS SMAN 2 Padang. Pencapaian atau tidaknya tujuan pembelajaran sosiologi dilihat dari hasil belajar. Hasil belajar merupakan tolak ukur yang digunakan untuk melihat seberapa besar tingkat keberhasilan siswa dalam memahami pelajaran sosiologi. Hasil belajar dapat berupa prestasi belajar dalam bentuk perubahan tingkah laku dalam diri individu. Ketika individu telah melakukan proses belajar, maka diharapkan tercapainya hasil belajar yang lebih baik. Terlihat hasil belajar siswa dapat dilihat dari nilai ujian mid semester Januari-Juni 2019 sebagai berikut:

\section{Tabel 1. Nilai Ujian Mid Semester 2 Mata Pelajaran Sosiologi Kelas XI IPS SMA N 2 Padang} Tahun Ajaran 2018/2019

\begin{tabular}{|c|c|c|c|c|c|c|}
\hline \multirow{3}{*}{ No } & \multirow{3}{*}{ Kelas } & \multirow{3}{*}{$\begin{array}{c}\text { Jumlah } \\
\text { Siswa }\end{array}$} & \multirow{3}{*}{ KKM } & \multirow{3}{*}{$\begin{array}{l}\text { Nilai Rata- } \\
\text { Rata }\end{array}$} & \multicolumn{2}{|c|}{ Kategori } \\
\hline & & & & & Tuntas & $\begin{array}{c}\text { Tidak } \\
\text { Tuntas }\end{array}$ \\
\hline & & & & & $\mathbf{N}$ & $\mathbf{N}$ \\
\hline 1 & XI IPS 1 & 34 & 80 & $74,64 \%$ & 13 & 21 \\
\hline 2 & XI IPS 2 & 33 & 80 & $79,54 \%$ & 21 & 12 \\
\hline 3 & XI IPS 3 & 35 & 80 & $76,37 \%$ & 15 & 20 \\
\hline
\end{tabular}

Sumber: Data tersebut berdasarkan hasil ujian Mid semester 2 kelas XI IPS 2018-2019

Berdasarkan tabel di atas terlihat bahwa nilai rata-rata ujian mid semester kelas XI SMA N 2 Padang mata pelajaran Sosiologi terlihat masih belum mencapai KKM.Tidak semua siswa bisa memperoleh hasil belajar yang baik, ada siswa yang memperoleh nilai sedang, dan ada yang memperoleh nilai kurang. Berdasarkan presentase nilai ujian mid semester tersebut kelas XI IPS 1 ada sebesar 74,64\% diantaranya ada 13 siswa yang tuntas dan ada 21 siswa yang belum tuntas. Siswa kelas XI IPS 2 ada sebesar 79,54\% diantaranya yang tuntas sebanyak 21 siswa sedangkan yang tidak tuntas 12 siswa. Sama halnya dengan kelas XI IPS 3 ada sebesar 76,37\% diantaranya yang tuntas sebanyak 15 orang dan yang tidak tuntas 20 orang. Hal ini

Jurnal Sikola: Jurnal Kajian Pendidikan dan Pembelajaran Vol. 1, No. 1, Th. 2019 
menunjukkan bahwa hasil belajar sosiologi siswa kelas XI IPS Tahun 2018/2019 masih tergolong Rendah.

Menurut Slameto (Nina Isnawati, 2012) Rendahnya hasil belajar siswa sebagaimana dipengaruhi oleh beberapa faktor yakni:

1. Faktor internal (faktor dari dalam diri siswa), yakni faktor jasmaniah (kesehatan, cacat tubuh), faktor psikologis (intelegsi, perhatian, minat, bakat, motivasi, kematangan, kesepian) dan faktor kelelahan.

2. Faktor eksternal (faktor dari luar siswa), yakni faktor keluarga (cara orang tua mendidik anak, relasi antara anggota keluarga, suasana rumah, keadaan ekonomi keluarga, perhatiam orang tua, latar budaya), faktor sekolah (metode mengajar, kurikulum, relasi guru dan siswa, relasi siswa dengan siswa, disiplin sekolah, alat pelajaran, standar pelajaran di atas ukuran, keadaan gedung, metode belajar, tugas rumah), faktor masyarakat (kegiatan siswa dalam masyarakat, mass media, teman bergaul, bentuk kehidupan masyarakat.

Menurut Djaali (dalam Suci Saraswati 2016) ada 2 faktor yang mempengaruhi belajar siswa dalam memperoleh pendidikan, faktor-faktor itu adalah faktor dalam diri dan faktor dari luar diri.

1. Faktor dari dalam diri, yaitu : Kesehatan, Intelegensi, Minat dan Motivasi, Cara Belajar

2. Faktor dari luar diri, antara lain : Keluarga, Sekolah, Masyarakat, Lingkungan Sekitar

Berdasarkan pendapat di atas salah satu faktor yang mempengaruhi hasil belajar faktor eksternal yaitu orang tua. Orang tua memiliki tanggung jawab untuk mendidik, mengasuh, membimbing anak dan memberikan perhatian untuk mencapai tahap tertentu yang mengarahkan anak untuk siap kehidupan masyarakat. Menurut Djamarah (Eliyana Koyimah, 2016) Indikator perhatian orang tua terdiri atas 5 yaitu: (1) Pemberian bimbingan (2) memberikan nasehat (3) memberikan motivasi dan penghargaan (4) memenuhi kebutuhan anak (5) pengawasan terhadap anak. Terlihat hasil data angket perhatian orang tua sebagai berikut:

Tabel 2 Data Perhatian Orang Tua Di SMAN 2 Padang

\begin{tabular}{clcc}
\hline \multirow{2}{*}{ No } & \multirow{2}{*}{ Indikator perhatian orang tua } & \multicolumn{2}{c}{$\mathbf{N = 5 0}$} \\
\cline { 3 - 4 } & & Jlh & $\mathbf{\%}$ \\
\hline 1 & Memberian bimbingan & 15 & $30 \%$ \\
\hline 2 & Memberikan nasehat & 20 & $40 \%$ \\
\hline 3 & Memberikan motivasi dan penghargaan & 25 & $50 \%$ \\
\hline 4 & Memenuhi kebutuhan anak & 27 & $54 \%$ \\
\hline 5 & Pengawasan terhadap anak & 29 & $58 \%$ \\
\hline & Rata-Rata & 25,2 & $46,4 \%$ \\
\hline
\end{tabular}

Sumber: Diolah dari data angket 2019

Dari tabel diatas untuk perhatian orang tua yang terdiri dari 5 indikator. Hasil dari 5 indikator tersebut ada beberapa indikator yang masih rendah seperti memberikan bimbingan, memberikan nasihat, memberikan motivasi dan penghargaan, memenuhi kebutuhan anak dan pengawasan terhadap anak. Berdasarkan penjelasan diatas bahwa orang tua kurang memberikan perhatiannya kepada anak, dapat dilihat dari hasil tabel diatas dengan hasil 46,4\%. Hal tersebut menunjukkan perhatian orang tua kepada siswa kelas XI IPS Tahun 2018/2019 masih tergolong Rendah.

Penelitian ini bertujuan untuk mengetahui apakah terdapat hubungan antara perhatian orang tua dengan hasil belajar sosiologi kelas XI IPS SMAN 2 Padang. Penelitian ini dianalisis

Jurnal Sikola: Jurnal Kajian Pendidikan dan Pembelajaran Vol. 1, No. 1, Th. 2019 
dengan teori yang dikamukakan oleh Gegne dan Berliner yang menganggap bahwa belajar adalah perubahan tingkah laku sebagai adanya interaksi stimulus dan respon.

\section{Metode Penelitian}

Menurut (sukardi, 2008) Penelitian ini termasuk jenis penelitian korelasional, dan bersifat kolerasi yakni bertujuan untuk mengetahui ada atau tidaknya hubungan antara dua variabel atau lebih. Penelitian ini menggunakan metode penelitian kuantitaif Ex-Post Facto. Penelitian kuantitatif dimana variabel-variabel bebas telah terjadi ketika penelitian mulai dengan pengamatan variabel terikat dalam suatu penelitian. Teknik pengumpulan data yang digunakan adalah proportional random sampling dengan jumlah responden 50 orang. Teknik pengumpulan data yang dilakukan dengan cara menyebarkan angket, data sekunder berupa hasil belajar dan dokumentasi. Menurut Endang Poerwanti (Sri Giarti, 2015) Penelitian ini dianalisis dengan mengunggunakan teknik analisisdeskriptif data.

\section{Hasil dan Pembahasan}

Ide studi ini dirancang untuk mempelajari seberapa besar hubungan perhatian orang tua dengan hasil belajar sosiologi siswa, direfleksikan menggunakan metodologi korelasional dari dua variabel di atas. Dalam pelaksanaannya menggunakan paradigma fisiologi yang berkonsep morfologi. Digunakan paradigma tersebut dimaksudkan untuk memudahkan pemecahan masalah penelitian, karena paradigma fisiologis morfologis adalah suatu model berikir berdasarkan perubahan fisiologi dalam rangka mencapai kondisi yang lebih baik, melalui pola adaptasi fungsional dari berbagai indikator perhatian orang tua. Penerapan suatu konsep dalam penelitian dimaksudkan untuk menajamkan hasil penelitian. Dalam penelitian ini, perhatian orang tua digunakan sebagai variabel bebas (indenpenden variabel) sedangkan hasil belajar adalah variabel terikat (dependen variabel). Kemampuan maksimal dalam penelitian ini didapatkan berdasarkan hasil penyebaran angket perhatian orang tua dan hasil belajar siswa. Berdasarkan hasil tes, maka perhatian orang dan hasil belajar masing-masing sampel dapat ditentukan. Sampel penelitian berjumlah 50 orang siswa kelas XI IPS SMA Negeri 2 Padang. Setelah proses pengambilan sampel selesai, dilakukan pendataan data mengenai perhatian orang tua dengan 5 indikator adalah indiaktor pemberian bimbingan, memberi nasihat, memberikan motivasi dan pernghargaan, memenuhi kebutuhan anak dan pengawasan terhadap anak serta hasil belajar terhadap variabel penelitian.

Berdasarkan pengukuran, dilakukan uji normalitas dan homogenitas. Hasilnya menunjukkan bahwa semua data berdistribusi normal dan homogen. Dalam penelitian ini digunakan analisis korelasi produck moment. Keluarga memiliki peran yang penting dalam mengurus pendidikan anak, sebab keluarga terutama orang tua adalah lingkungan dan orang pertama yang dikenal anak. Menurut Walgino (Siska \& Nurhasanan, 2017) perhatian ialah kefokusan atau konsentrasi di seluruh aktivitas individu ditunjukan kesesuatu atau sekelompok obyek. Menurut Soemanto (Ani Endriani, 2016) Perhatian yaitu cara mengerakkan bentuk umum cara bergaulnya jiwa dengan bahan-bahan dalam medan tingkah laku. Menurut Sumadi Suryabrata (Rani Febriany, 2013) mengatakan bahwa perhatian ialah sedikit banyaknya kesadaran yang menyertai suatu aktivitas yang dilakukan.

Pendapat dari diatas dapat dikatakan bahwa perhatian merupakan pemusatan/kekuatan terhadap tingkah laku serta aktivitas siswa secara sadar yang ditujukan untuk anak. Bentuk perhatian ini dapat berupa memberikan bimbingan, nasihat, motivasi dan penghargaan, memenuhi kebutuhan anak serta pengawasan terhadap anak. Menurut Soelaeman (dalam Rikani \& Djihad, 2012) istilah orang tua hendaknya tidak diartikan sebagai orang yang dituakan dan karenanya diberikan tanggung jawab untuk merawat dan mendidik anak menjadi manusia dewasa. Sementara itu hasil belajar dapat diartikan sebagai dasar untuk menentukan tingkat keberhasilan siswa dalam memahami suatu materi pelajaran. Menurut Nana Syaodih (Rini, 
2012) Hasil belajar yaitu perubahan-perubahan yang terjadi pada diri siswa, baik yang menyangkut aspek kogniftif, afektif dan psikomotorik sebagai hasil dari kegiatan belajar. Hal ini senada dengan pernyataan Gaagne (Remon, 2014) bahwa hasil belajar merupakan kemampuan yang diperoleh dari proses belajar yang dapat dikategorikan dalam empat macam yaitu (1) informasi verbal, (2) keterampilan intelektual strategi kognitif, (3) sikap dan (4) keterampilan motorik. Seorang siswa yang memahami tujuan belajar akan bersikap selalu ingin tahu, aktif dalam kegiatan pembelajaran, memperhatikan pelajaran dengan sek- sama, dan mau mengulang pelajaran. Dengan sikap yang demikian, maka siswa akan mampu memperoleh hasil belajar yang tinggi. (Sylvia, 2014)

Meskipun pada kenyataan dilapangan ada kalanya siswa yang mendapatkan perhatian orang tua dengan kategori baik, belum tentu diikuti dengan hasil balajar yang baik pula, begitu juga sebaliknya rendahnya hasil belajar belum tentu juga dikarenakan rendahnya perhatian orang tua.

Merujuk pada hasil analisis penelitian yang membuktikan bahwa terdapat hubungan yang signifikan antar perhatian orang tua dan hasil belajar sosiologi khususnya siswa kelas XI SMA Negeri 2 Padang dengan koefisien korelasi sebesar $\left(r_{x y}\right) 0.778$ besar dari $r_{\text {tabel }} 0.279$. Dengan nilai determinasi $\left(\mathrm{r}^{2}\right)$ adalah 0.605 atau $60.5 \%$. Artinya hasil belajar $60.5 \%$ dipengaruhi oleh perhatian orang tua dan sisanya dipengaruhi oleh faktor lain. Sebagaimana yang dibuktikan hasil korelasi masing-masing indikator, jelasnya dapat disajikan pada tabel berikut:

Tabel 3. Hasil Uji Korelasi Indikator Perhatian Orang Tua dengan Hasil Belajar

\begin{tabular}{|c|c|c|c|c|}
\hline No & Indikator Perhatian Orang Tua & r hitung & r tabel & Keterangan \\
\hline 1 & Pemberian Bimbingan & 0.804 & \multirow{5}{*}{0.279} & Berkorelasi \\
\hline 2 & Memberi Nasihat & 0.697 & & Berkorelasi \\
\hline 3 & $\begin{array}{l}\text { Memberikan Motivasi dan } \\
\text { Penghargaan }\end{array}$ & 0.623 & & Berkorelasi \\
\hline 4 & Memenuhi Kebutuhan Anak & 0.579 & & Berkorelasi \\
\hline 5 & Pengawasan terhadap Anak & 0.535 & & Berkorelasi \\
\hline
\end{tabular}

Sumber: Pengolahan Data Primer, 2019

Dari tabel di atas dapat dilihat bahwa perhatian orang tua siswa, keseluruhan indikator memberikan kontribusi terhadap hasil belajar siswa. Yang dibuktikan dengan nilai $r$ hitung lebih besar dari r tabel. Jelasnya dapat dipaparkan sebagai berikut:

\section{Pemberian Bimbingan}

Indikator pertama dari variabel perhatian orang tua yaitu pemberian bimbingan memiliki hubugan yang signifikan dengan hasil belajar siswa yang dibuktikan dengan nilai $r$ hitung = $0.804>\mathrm{r}$ tabel $=0.279$. Indikator pemberian bimbingan memberikan konstribusi sebesar $64.64 \%$ terhadap hasil belajar. Artinya perhatian orang tua dalam pemberian bimbingan memiliki hubugan yang signifikan dan memberikan kontribusi yang berarti terhadap hasil belajar.

\section{Memberi Nasihat}

Indikator kedua dari variabel perhatian orang tua yaitu memberi nasihat memiliki hubugan yang signifikan dengan hasil belajar siswa yang dibuktikan dengan nilai $\mathrm{r}$ hitung = $0.697>\mathrm{r}$ tabel $=0.279$. Indikator memebri nasihat memberikan konstribusi sebesar $48.58 \%$ terhadap hasil belajar. Artinya perhatian orang tua dalam memebri nasihat memiliki hubugan yang signifikan dan memberikan kontribusi yang berarti terhadap hasil belajar. 


\section{Memberikan Motivasi dan Penghargaan}

Indikator ketiga dari variabel perhatian orang tua yaitu memberikan motivasi dan penghargaan memiliki hubugan yang signifikan dengan hasil belajar siswa yang dibuktikan dengan nilai $r$ hitung $=0.623>\mathrm{r}$ tabel $=0.279$. Indikator memberikan motivasi dan penghargaa memberikan konstribusi sebesar $38.81 \%$ terhadap hasil belajar. Artinya perhatian orang tua dalam memebrikan motivasi dan penghargaan memiliki hubugan yang signifikan dan memberikan kontribusi yang berarti terhadap hasil belajar.

\section{Memenuhi Kebutuhan Anak.}

Indikator keempat dari variabel perhatian orang tua yaitu memenuhi kebutuhan anak memiliki hubugan yang signifikan dengan hasil belajar siswa yang dibuktikan dengan nilai $\mathrm{r}$ hitung $=0.579>\mathrm{r}$ tabel $=0.279$. Indikator memenuhi kebutuhan anak memberikan konstribusi sebesar $33.52 \%$ terhadap hasil belajar. Artinya perhatian orang tua dalam memenuhi kebutuhan anak memiliki hubugan yang signifikan dan memberikan kontribusi yang berarti terhadap hasil belajar.

\section{Pengawasan Terhadap Anak.}

Indikator kelima dari variabel perhatian orang tua yaitu pengawasan terhadap anak memiliki hubugan yang signifikan dengan hasil belajar siswa yang dibuktikan dengan nilai $\mathrm{r}$ hitung $=0.535>\mathrm{r}$ tabel $=0.279$. Indikator pengawasan terhadap anak memberikan konstribusi sebesar $28.62 \%$ terhadap hasil belajar. Artinya perhatian orang tua dalam pengawsan terhdap anak memiliki hubugan yang signifikan dan memberikan kontribusi yang berarti terhadap hasil belajar. Hubungan perhatian orang tua dengan hasil belajar siswa dianalisa dengan teori behavioristik. Teori behavioristic mengemukakan, belajar sebagai perubahan tingkah laku sebagai reaksi danya interaksi dari stimulus dan respon. Hal yang utama dalam teori ini adalah respon sebagai bentuk dari stimulus dan keluaran atau output.

\section{Penutup}

Secara umum terdapat korelasi yang signifikan antra variabel perhatian orang tua dengan hasil belajar sosiologi siswa kelas XI IPS di SMA Negeri 2 Padang yang dibuktikan dengan koefisien korelasi $\left(r_{\mathrm{xy}}\right) 0.778>\mathrm{r}$ tab (0.279). Uji hipotesis per indikator perhatian orang tua dengan hasil belajar sosiologi siswa menunjukkan terdapat hubungan signifikan dan memberikan kontribusi yang bermakna.

\section{Daftar Pustaka}

Ani Endriani. (2016). Hubungan Perhatian Orang Tua dengan Motivasi Belajar pada Siswa Kelas VIIIi Smpn 6 Praya Timur Lombok Tengah. Journal.

Aris Nanda, Yunus, M., \& Hayati, E. (1991). Hubungan Antara Perhatian Orang Tua Dengan Prestasi Belajar Pkn Pada Siswa MTSN Tungkob. Journal, 1(1), 227-229.

Eliyana Koyimah. (2016). Hubungan Perhatian Orang Tua Dengan Hasil Belajarips Pada Siswa Kelas $V$ Sdndigugus Ki Hajar Dewantara Kabupaten Semarang. 4(1), 19. https://doi.org/10.23819/mimbar-sd.v4i1.6346

Melgawati. (2014). Kepedulian Orang Tua Dengan Hasil Belajar Siswa Kelas Xi IPS SMAN 8 Padang.

Nina Isnawati, D. S. (2012). Pengaruh Perhatian Orang Tua Dan Motivasi Belajar Siswa Terhadap Prestasi Belajar Akuntansi Pada Kompetensi Mengelola Dokumen Transaksi Siswa Kelas X Program Keahlian Akuntansi Smk Cokroaminoto 1 Banjarnegara. Jurnal Pendidikan Akuntansi Indonesia, X(1), 66-77.

Rani Febriany, Y. (2013). Hubungan Perhatian Orangtua Dengan Motivasi Belajar Siswa Dalam Mengerjakan Tugas-Tugas Sekolah. 2(2), 8-15.

Jurnal Sikola: Jurnal Kajian Pendidikan dan Pembelajaran Vol. 1, No. 1, Th. 2019 
Remon. (2014). Pengaruh Komunikasi Interpersonal Keluarga Dan Minat Belajar Terhadap Hasil Belajar Ekonomi Siswa Kelas X Smkn 1 Solok Selatan JurnaL Diajukan Sebagai Salah Satu Syarat untuk Memperoleh Gelar Sarjana Pendidikan S1 ( Strata I ) REMON NPM: 09090026 Pembimb. Journal.

Rini, E. S. (2012). Hubungan Tingkat Pendidikan Orang Tua Dan Prestasi Belajar Siswa Dengan Minat Siswa Melanjutkan Studi Ke Perguruan Tinggi Pada Siswa Kelas Xi Sma Negeri 1 Kalasan. Journal, 5(28 (3)), 13-15.

Siska, S., \& Nurhasanan. (2017). Pengaruh Perhatian Orang Tua Dan Motivasi Belajar Terhadap Peningkatan Prestasi Belajar Siswa. Jurnal, 2(1), 1-13. https://doi.org/10.30870/jpbk.v2i1.3023

Soerjono. (2003). Sosiologi Suatu Pengantar. Jakarta: Raja Grafindo Persada.

Sri Giarti. (2015). Peningkatan Keterampilan Proses Pemecahan Masalah Dan Hasil Belajar Matematika Menggunakan Model PBL Terintegrasi Penilaian Autentik Pada Siswa Kelas Vi SDN 2 Bengle, Wonosegoro Sri. (november), 6.

Sukardi. (2008). Metodelogi Penelitian Pendidikan. Jakarta: Bumi Aksara.

Sylvia, I. (2014). Jurnal Diakronika, Vol. XIV No 1. Th 2014. Diakronika, XIV(1). https://doi.org/https://osf.io/preprints/inarxiv/6yz2w/ 